\title{
Tertiary Education, Vocational Training and Lifelong Learning for Adults with Autism: Comparing Domestic Laws and Best Practices
}

\author{
Lucia Chiappetta Cajola
}

\section{Introduction}

This paper is inspired by the need to disseminate and share knowledge on the status of adults with Autism Spectrum Disorders (ASD) with regard to higher education, ${ }^{1}$ vocational training and lifelong learning, whether as a result of national legislations and the more accredited scientific research or due to the multiple operational approaches proposed in different regional and local contexts, as well as through good practices.

The overall picture will be enhanced by a look at the international situation, providing a kind of survey of the laws and regulations that govern these areas, the situation in Italy and that of some European countries. Although Italy is productive in protecting the rights of persons with disabilities (Law no. 104/1992, Presidential Decree, 24 February 1994, Law no. 17/1999, Law no. 68 of 23 March 1999, Law no. 328/2000, Law no. 53/2003, and the Prime Ministerial Decree of 29 November 2001), where persons with autism are concerned, legislation is lacking.

The situation regarding the general rights of the disabled which also relate to autism will be covered (in the United Kingdom, France and Germany) as well as those which refer specifically to autism (Poland and Hungary). In this context, the significant contribution by Autism-Europe ${ }^{2}$ to international literature in relation to

\footnotetext{
${ }^{1}$ Not only in the case of autism, but also in other types of disability, there is a need for access to knowledge, information and data. These are, in fact, very difficult to acquire, both nationally and internationally. See Chiappetta Cajola (2014).

${ }^{2}$ This is a European network which brings together some 80 associations of parents of persons with autism in 31 countries, including EU Member States, with the aim of promoting the defence of the rights of people with autism and their families, as well as improving their quality of life. AutismEurope is a founder member of the Platform of European Social NGOs and the European Disability Forum.

L. Chiappetta Cajola $(\bowtie)$

University Roma Tre, Rome, Italy

e-mail: lucia.chiappettacajola@uniroma3.it
} 
adults with autism is also considered, their having produced, amongst other things, the 'Charter of Rights for Persons with Autism', adopted by the European Parliament. Autism-Europe is committed to collecting national legal cases to allow them to make an analysis of the state of the rights to education for persons with autism. ${ }^{3}$

Particular attention is also paid to proposals for regional Italian laws, among which are highlighted no. 427 of 21 July 2014, Disposizioni in Materia di Disturbi dello Spettro Autistico (Provisions on Autism Spectrum Disorders), issued by the Marche region and approved on October 7 2014, following the various draft laws put forward by some other regions (Abruzzo, Campania, Emilia Romagna, Lazio, Liguria, Marche, Piedmont, Sardinia, Tuscany, the Autonomous Province of Trento, Umbria, Valle d'Aosta, and Veneto) which were collected in the unified text adopted by the committee for draft laws. ${ }^{4}$ During this research, the initiatives taken by the foundations (e.g., Marino, Serono, Sacra Famiglia, Oltre il Labirinto) and associations (e.g., ANGSA, Gruppo Asperger, Associazione Genitori Autismo non-profit organization) were particularly interesting. By carrying out a prominent role in social and welfare activities, they engage in policy guidance for training and integrating adults with autism in the workplace which, in Italy, give rise to best practices. Among these activities, those promoted on a regional or local level provide important relevant information relating, in particular, to tertiary education. They give accounts of some of the main groups (Insettopia, a social network, the 'Job Trainer Disability' project; Autismo e lavoro agricolo [Autism and agricultural work], the Sotto-Progetto per l'Istituzione di Servizi per Adolescenti ed Adulti con Disturbi Autistici [Sub-Project for the Establishment of Services for Adolescents and Adults with Autistic Disorders], etc.) and describe implements for innovations and their application, which may be true operational models for further regional and local projects to improve vocational training and lifelong learning for people with autism.

\section{The Evolution of Autism in Adulthood and Diverse Measures}

Once his schooling is finished, the person with autism and his family very often run the risk of being 'forgotten' by society and find themselves isolated or forced to refer to services that are not always adequately and properly organized to take responsibility and manage their needs. ${ }^{5}$ The difficulties of personal and

\footnotetext{
${ }^{3}$ The law is an important source of jurisdiction; in fact, a court decision is binding, and takes the value of a precedent, which may be invoked in further legal cases. In this context, a legal appeal against non-observance of fundamental rights represents an essential process towards the defence of these rights and allows the texts concerning integration or social integration to become a reality.

${ }^{4}$ Summary no. 109 of 3 April 2014.

${ }^{5}$ Cottini (2010), p. 196.
} 
interpersonal communication, in addition to cognitive-behavioral problems, make the path towards social autonomy very difficult for individuals with autism and, therefore, there is a very high risk of being cared for exclusively by the family or being placed in institutions which, for various reasons, do not specifically aim to integrate them into community life in a concrete way.

At present, the necessary sensitivity for the problems of adults with autism still does not exist. Although attention to the study of autism in childhood is relevant; sensitivity towards family members is completely lacking, for whom the end of school signifies the most critical moment. ${ }^{6}$ The parents themselves, in fact, are faced with the complexity determined by the disorder which, over time, becomes increasingly difficult to manage: the lack of independence, more frequent and intense aggressive actions towards self and others, autistic symptoms in general occurring ever more clearly, without further improvements after those achieved during childhood and adolescence. ${ }^{7}$ Therefore, it is urgent that measures and effective procedures are developed from a careful survey of the currently available and reliable scientific data; in this respect, the synthesis proposed by some scholars is interesting:

At the present state of knowledge it is possible to indicate some 'almost certainties':

1. The vast majority of autistic people will never be independent. Many will make even significant progress in mental and social functioning, but very few will become autonomous. Almost all adults with autism will therefore need a safe living environment.

2. It is difficult to establish a relationship between types of treatment and outcomes. The type of measure affects the appearance of the skills and competencies facilitated. In any case, the handicap should never be treated as a statistic, under the banner of 'all or nothing', but as a set of functions in which, however, traces are to be found, so one can try to stimulate where and how it is possible. ${ }^{8}$

The basic global line would appear to be related, not so much with individual types of measures (there is still not enough evidence for this) as to the constancy, systematicity, the length of the treatments, their internal consistency, their ability to create and maintain, however, a climate of constant investment and emotional support around the autistic. It is necessary to consider what to do next.

The evolutions of autism in adulthood are very diverse. Even the type of treatment should be differentiated. As far as the types of measures are concerned, it is evident that an adult with autism who has developed strong social skills could usefully form part of a non-residential community support network, and maybe enjoy supported employment and in some cases live independently or in partly-

\footnotetext{
6 'The network of services, which at this stage is critical to the family of the person with autism should provide greater support, in reality extend its links; once adolescence has passed, the autistic is progressively 'abandoned' by the services of paediatrics and infant neuropsychiatry, as well as the educational and rehabilitative function of school placement. Therefore, an assessment of the autistic adult plays a role of the utmost importance for his inclusion in the most suitable rehabilitative context'. Alessandroni (2010), p. 196.

${ }^{7}$ Howlin et al. (2004).

${ }^{8}$ Uccelli di Nemi and Barale (2010), pp. 196-197.
} 
independent assisted facilities. But this concerns, however, a small minority of adult autistics. The others should also be considered.

In Europe and the USA there are three types of more protected measures: communities for autistics, apartments for autistic groups and mixed apartments for communities or groups. Each of these choices has its problems, advantages and specific difficulties. This paper focuses on agricultural and residential communities. The movement towards farm communities for autistics started at the end of the 1960s and spread throughout the Western world, the communities generally being promoted by organizations or groups of parents. Their fortune and the interest they have aroused are due to the fact that their characteristics are particularly suited to the following requirements:

a) they create places to live and work and they provide treatment; they are secure, pleasant, orderly, consistent and at the same time full of stimuli, offering the chance for significant work experience;

b) they are places to live, therefore, in which the need for stability, consistency, and predictability, etc. can be respected;

c) they are places where various psychoeducational, therapeutic or rehabilitative treatments do not take place in an abstract, fragmented and demotivating environment, but in 'natural settings', which are closely linked to one another, together with the experiences of having both a working life and leisure time;

d) moreover, these are sites for adults, i.e. 'places to live and work' which, although protected, are not a repetition of infantile patterns, but areas of adult life.

In fact, in all the communities for which documentation is available, a significant clinical improvement has been obtained in their living conditions, with a reduction in behavioural problems and the use of drugs. It is here that learning skills and rehabilitation are an active and valued synergy, since they establish an improvement in the abilities of communication and expression in adolescent and adult autistics. There are numerous studies ${ }^{9}$ that have demonstrated through empirical research and the use of assessment tools, that the diagnosis of autism remains almost stable throughout life. In adulthood, in particular, symptoms which characterize autistic syndromes are more evident, especially in the context of difficulties in social interaction and communication. ${ }^{10}$ Not only that, but the abnormalities in processing sensory stimuli encountered in children with autism are present in $94.4 \%$ of the sample of adults examined in a study by Crane, Goddard and Pring using the AASP (Adult/Adolescent Sensory Profile, 2009). ${ }^{11}$ These findings regarding the persistence and severity of symptoms are significant of the poor quality of life of adults with autism, both with respect to cognitive abilities as well as social ones, without prejudice towards the better outcome for high-functioning than for

\footnotetext{
${ }^{9}$ Seltzer et al. (2004).

${ }^{10}$ Matson and Smith (2008).

${ }^{11}$ Raffin (2010), p. 1.
} 
low-functioning adults. ${ }^{12}$ Nevertheless, there are few high-functioning autistic individuals who lead an independent life and who have permanent employment. Most of them remain dependent on family and support services. ${ }^{13}$

\subsection{Measures in Italy Compared to Europe in General}

As far as job opportunities in Italy are concerned, there are three types of 'employment' for autistics: sheltered workshops, supported employment or prevocational training for competitive employment.

Sheltered workshops welcome people with autism, who perform an occupational activity whose main objective is not to give them a working activity in itself, but rather to 'keep them busy' to market products or services resulting from such activities. 'In this way, the value of work as a vehicle for self-assertion and selfesteem has been seriously compromised and the lack of a real economic value (workshops do not finance themselves with what they produce, but are subsidized by the public services) permits exemption from many duties such as responsibility, quality, punctuality, productivity, etc. which are at the base of the individual and social growth represented by work'. ${ }^{14}$

Job placement in Italy is regulated by the Law no. 68, 12 March 1999, Norme per il diritto al lavoro dei disabili (Standards for the right to work of persons with disabilities), ${ }^{15}$ which has the aim of promoting the inclusion and integration of people with disabilities into the labour market through support services and targeted employment (Article 2). The latter puts the right person in the appropriate workplace, supporting him with appropriate incentives and facilities, as most recently reaffirmed by the Presidential Decree of 4 October 2013: Adozione del programma di azione biennale per la promozione dei diritti e l'integrazione delle persone con disabilità (Adoption of the biennial programme of action for the promotion of the rights and inclusion of people with disabilities). The Decree proposes, as a first step, a definition of the guidelines to operate services for targeted placements and then to disseminate all available data digitally.

Law no. 68/1999 introduces several critical points, particularly for people with severe mental disabilities and with autism. ${ }^{16}$ In fact, according to the Diario di transizione/3 (Diary of transition/3) by Censis (in which more important issues

\footnotetext{
${ }^{12}$ McGovern and Sigman (2005).

${ }^{13}$ Billstedt et al. (2010).

${ }^{14}$ Ibid.

${ }^{15}$ The Law is published in Official Gazette no. 68, 23 March 1999_Ordinary Supplement no. 57.

${ }^{16}$ According to a study conducted in 1999 by the Osservatorio Autismo (Autism Observatory) in the Lombardy Region, even though the autistic adults identified in that region (approximately 145) were in a protected type of employment, none was active either at a higher level or in productive competition on the market.
} 
were identified and described on the agenda for the spring-summer period 2014), by 2020 , there will be about 4.8 million people with disabilities (7.9\% of the European population), and currently, only $10 \%$ of autistic individuals over 20 years old work, although the age range is wider: $15-44$ years, equal to $66 \%$. It is well understood, therefore, that the main reason our welfare system is based on an informal model is that response to the needs of adults with autism, is represented by families, ${ }^{17}$ whose access to institutional support is very limited, being exclusively of an economic nature. By making a comparison with other European countries it can be seen that spending on social protection benefits for disability amounts to 437 euros per capita per year, higher only than the figure in Spain (404 euros), and significantly lower than the European average (535 euros). The percentage of the service charge, which is only $5.8 \%$ of the total (25 euros per capita per year) is particularly significant: it is less than a fifth of the EU average and even lower than the figure for Spain. ${ }^{18}$ In Italy, among people with autism aged 21 years and older, $50 \%$ attend a daycare centre, but $21.7 \%$ of them do not do any kind of working activity. ${ }^{19}$ From the statistical data, then, it emerges that care management of people with autism is almost totally borne by the family. The controversy, however, does not concern only Italy, to the point that Autism-Europe has strongly emphasized the need for adequate training in specific needs in the field of continuing education and vocational training, adapted not only to develop job skills, but also the social and personal skills necessary to access, really and effectively, a job or profession. As far as this is concerned, in the years 2001-2002, Autism-Europe had already launched a survey ${ }^{20}$ among its members and those of relevant European organizations, by means of a questionnaire, translated into eight languages, focusing on the problems of working-age people with autism and their families. The most important point emerging from this survey is that, in the vast majority of cases, autistic people 'do not want to or cannot work' $(61.5 \%)$. Speaking of which, there remains the fact that only $37 \%$ of autistic individuals receive professional and/or continuous training. The consequence is, of course, a lack of participation in social life.

\footnotetext{
${ }^{17}$ The families become, in most cases, the central subjects of care who, despite their efforts, suffer from emargination and isolation in turn, especially when the children reach adulthood and complete their path of studies. Throughout childhood, in fact, the parents of children and adolescents with autism may enjoy the integration and inclusion that occurs in schools, the pride of the Italian institutions. Suffice it to say that, according to a survey by Censis, it was recorded that up to 19 years old, $93.4 \%$ of subjects with autism spectrum disorders attend school, but the figure drops considerably to $61.4 \%$ between 14 and 20 years, and goes even lower, to exactly $6.7 \%$, for those over 20 years old.

${ }^{18}$ Censis (2014).

19 'Between the hours available for support and those of mere supervision, parents of people with autism and Down syndrome spend 17 hours a day together. The economic value of this time [...] comes to a truly substantial annual amount [...]: approximately 51,000 Euros for people with Autism Spectrum Disorders' (Ibid).

${ }^{20}$ The data pertaining thereto are available from the Secretariat of Autism-Europe and on their Web pages.
} 
The initiatives promoted by the European Union in the field of combating discrimination, in particular the directive in favour of 'equal opportunities in employment and occupation', ${ }^{21}$ adopted by the Council in November 2000, have not yet received adequate responses in favour from those with autism and their families.

In Italy, too, the efforts to include such adults socially and in the labour market are rather weak. Although the context of the needs and difficulties has been defined as a result of the Tavolo nazionale di lavoro sull'autismo (National Working Table on Autism), effective and sufficient measures and funding have not followed. Currently, there is not available, in fact, an organized network of public services responsible for people with autism and, for most situations, there is a no homogeneous reality able to respond effectively to the growing request by family members and the institutions themselves for help in the management of their everyday life.

Given, therefore, the decades of copious Italian legislation in the field of education and school and the social integration ${ }^{22}$ of students with disabilities, an analysis by Autism-Europe notes that both national laws and international standards allow, in general, an effective guarantee of the right to education of persons with disabilities, also recognized in court proceedings. However, the legislative path concerning access to employment for people with disabilities is different, as stated above.

\section{Continuous Training and Job Placement in the Context of the UN Convention and the European Disability Strategy 2010-2020}

The 'UN Convention on the Rights of Persons with Disabilities' is the 'first legallybinding instrument in the field of human rights' to which the European Union has adhered. ${ }^{23}$ The Convention requires the states to protect and safeguard all human rights and the fundamental freedom of persons with disabilities. ${ }^{24}$ Among the topics

\footnotetext{
${ }^{21}$ European Union Council Directive no. 2000/78/EC, 27 November 2000, Establishing a general framework for equal treatment in employment and occupation.

${ }^{22}$ See Article 3 of the Constitution; Law no. 118/1971, Law no. 517 (1977), Law no. 104 (1992), Presidential Decree, 24 February 1994. Note of the 4 August 2009, protocol no. 4274.

${ }^{23}$ Communication from the Commission to the European Parliament, the Council, the European Economic and Social Committee and the European Committee and the Committee of the Regions (2010). European Disability Strategy 2010-2020: A Renewed Commitment to a Europe without Barriers. Brussels, 15 November 2010.

24 'That which characterizes the UN Convention in question is that it has definitely exceeded an approach focused solely on the deficit of the disabled person, by accepting the 'social model' of disability and introducing the principles of non-discrimination, equal opportunities, autonomy and independence with the aim of achieving full social inclusion through the involvement of people with disabilities themselves who, in less favoured contextual conditions, are difficult to reach. [... .] For this purpose it is necessary that the context (environment, procedures, educational tools and aids) fits the specific needs of people with disabilities, through what the Convention defines 'reasonable accommodation' [...].' (Note 4 August 2009, protocol 4274-Policy guidelines on inclusion in education of disabled students, Part I, Item 2).
} 
of this paper, those of specific relevance are Articles 24 and 27 dedicated to education, and labour and employment, respectively. In detail, Article 24(5) states: 'Party states shall ensure that persons with disabilities are able to access general tertiary education, vocational training, adult education and lifelong learning without discrimination and on the basis of equality with others. To this end, party states shall ensure that proper accommodation is provided for persons with disabilities'. Article 27(1) strongly states that, 'member states recognize the right of persons with disabilities to work, on an equal basis with others; this includes the right to the opportunity to support oneself through work, freely chosen or accepted in a labour market and work environment that is open, inclusive and accessible to persons with disabilities. Party states shall safeguard and promote the exercise of their right to work, including those who acquire a disability during employment, by taking appropriate steps-including through legislation'. In order to place people with disabilities in an optimal condition to exercise their rights and enjoy full and active participation in social life the 'European Disability Strategy 2010-2020' has identified eight main areas for action: accessibility, participation, equality, employment, education and training, social protection, health and external actions. ${ }^{25}$ In terms of occupation, the aforementioned European Strategy states that 'to achieve the goals of growth in the EU, it is necessary that people with disabilities in paid employment are more numerous on the open labour market. The Commission will use the full potential of the Europe 2020 strategy and its programme for the renewal of skills and labour, making available to member states: analyses, policy guidance, information and other forms of aid. It will improve information on the employment situation of men and women with disabilities, identify problems and propose solutions, with particular attention to young people with disabilities in their transition from education to the world of work' ${ }^{26}$ Within the outlines concerning tertiary education, vocational training and lifelong learning, the following pages on the state of the art related to these issues, with reference to adults with autism, is analysed in Italy and in Europe, also in order to verify consistent application of the existing rules.

\footnotetext{
${ }^{25}$ These sectors have been identified by virtue of their potential contribution to achieving the objectives of the strategy itself: the UN Convention, documents of the institutions of the European Union and the Council of Europe, the EU action plan for disabled people 2003-2010, and public consultations with member states and stakeholders.

${ }^{26}$ European Disability Strategy 2010-2020 (2010). Section 4. Employment.
} 


\subsection{The Effectiveness and Protection of Rights in Some European Countries}

In the international arena, relating to the effectiveness of rights and their protection at a jurisdictional level, ${ }^{27}$ interesting decisions have been made in which the court has recognized the state's responsibility for the fulfilment of the rights enshrined in the UN Convention. ${ }^{28}$ For the purposes of this paper, it is useful to underline that the European Committee of Social Rights, in commenting on the specific case of Autism-Europe v France, Complaint no. 13/2002, defined that the task of the State is to take concrete measures to ensure the effective protection of the rights referred to in the aforementioned 'Charter for autistic people'. ${ }^{29}$ This case is presented here as an example to understand how, even in an international context, the scarcity of resources does not constitute an element of legitimacy, but is rather a determining factor for measures aimed to protect and ensure the effective fulfilment of rights, including those of education, social inclusion, and integration into the labour market of people with disabilities. The example shows that the French government continued to adopt a restrictive definition of autism compared to that adopted by the World Health Organization, without considering the scarcity of statistical data related to progress in the right to education. ${ }^{30}$ The Committee therefore, held that France had not made any progress towards the full guarantee of education for people with autism. This decision is of great importance regarding tutelage and focuses on the issue of recognition as a form of state responsibility, as a key to ensure a guarantee of the right to education. Due to this, the French judges made the decision to compensate the families of people with autism spectrum disorders, recognizing the responsibility of the state; nevertheless, by virtue of the legal framework, the courts have not found concrete solutions. ${ }^{31}$

\footnotetext{
${ }^{27}$ This is the concept of giustiziabilità (the ability to make a judicial decision) and the possibility to have recourse to an independent and impartial body that can guarantee the fulfilment of the infringed right.

${ }^{28}$ See the case People's Union For Civil Liberties v Union of India and Others, Supreme Court of India-HCJ 2599/00, 14 August 2002.

${ }^{29}$ The committee also pointed out that, in the event that such a guarantee is complex and costly, the state may use measures to ensure a progressive and real pursuit of the right (in the case of France, it was the right to education), considering the effect that such a choice would mean for the community as a whole.

${ }^{30}$ This narrow definition of autism has produced such severe consequences that a very small number of children with autism has been able to take advantage of special services for education.

31 'In a decision on 13 October 2005, the administrative tribunal of Lyon ordered the state to pay 36,000 euros, by way of compensation, to the parents of a teenager with autism who had not 'received educational support for more than three years'. More specifically, the courts recognized the responsibility of the state for the period during which the boy had not received any education. However, because of 'the efforts made by the state to respond to the needs of the boy', the judges considered that the state, though responsible, did not err'. Giofrè (2010), p. 57.
} 
In 1998, Ireland promulgated an anti-discrimination law, the Employment Equality Act, which declared discrimination in employment unlawful, consenting action in favour of all persons with disabilities, and with the intention of securing their social and professional integration. In Germany, the principle of nondiscrimination is governed by the Disability Discrimination Act, and in 1993, in England and Wales, a special and independent court was set up (SENDIST, Special Educational Needs and Disability Service Tribunal) with the task of deciding on the specific needs of people with disabilities in the educational field. ${ }^{32}$

Among the European countries that have given significant and specific attention to the plight of people with autism, it should be noted that England boasts the first law on Autism Spectrum Disorders, the 'Autism Act', ${ }^{33}$ which outlines expected standards of care practices and establishes the legal obligation to provide services and adequate support for adults with autism. It is, by far, the first law dedicated to a specific disability and establishes the duty, on the part of the Minister of Health, to develop and publish a document setting out a strategy to meet the needs of adults with Autism Spectrum Disorders in England and Wales. ${ }^{34}$

Hungary is the first country in Europe to have ratified the UN Convention on the Rights of Persons with Disabilities and the government adopted in 2008 a 'National Strategy for Autism' which specifies the actions to be taken by Hungarian ministers for the years 2008-2013. The development of the Strategy was coordinated by the Hungarian Autistic Society and the national network of Magyar non-profit organizations active in the field of Autism Spectrum Disorders. ${ }^{35}$ Moreover, the Act CXXXIX of 2005 on Higher Education expressly applies to students with autism. ${ }^{36}$

In Poland, legislation on the subject of education is very precise and targeted, and takes into account the rights of people with disabilities, specifically people with autism. However, as can be seen from a study by Autism-Europe, notwithstanding the fact that appropriate regulatory acts and financial loans have been promulgated,

\footnotetext{
32 'And in one particular case that body acknowledged that in practice the only way for [...] the teenager to receive a sufficient and appropriate education in terms of academic and social learning, which could lead to a more independent life, consisted of taking specific responsibility for autism and placing him in a residential centre, regardless of the cost, which in reality had represented the obstacle that the local authorities had found in guaranteeing the adolescent the right to receive a suitable education for his state'. Ibid, p. 57.

${ }^{33}$ The Act received Royal Assent on 12 November 2009.

${ }^{34}$ On this Strategy see the chapter by V. Della Fina, in this volume.

${ }^{35}$ This process was carried out to implement a coherent plan of social and educational policies and, in parallel, to plan the development of the institutional system. The strategy was inserted into section IV/3 of the Hungarian Government Decree 1062/2007 on the fulfillment of the national programme for issues of disability for the period 2007-2010.

${ }^{36}$ Section 147 (8) of the Act states: 'Student (applicant) with disability means a student (applicant) who suffers from physical, sense, speech disorders, autism, and disorders in cognitive and behavioural development' (http://www.nefmi.gov.hu/letolt/nemzet/naric/act_cxxxix_2005.pdf). For all websites, last access 31 October 2014.
} 
the educational services offered are quantitatively and qualitatively insufficient to meet their demands and needs. ${ }^{37}$

\section{People with Autism in European Legislation}

The 'Charter of Rights for Persons with Autism' is a paper, presented at the fourth Autism-Europe Congress held in The Hague on 10 May 1992, which was adopted by the European Parliament in May 1996 in the form of a written declaration. It emphasizes the importance for people with autism to enjoy the same rights as all people in Europe, as far as they can, taking into account their best interests. It is also stated that these rights should be highlighted, protected and made operational through appropriate legislation in each state, taking into account the UN Declaration on the Rights of the Mentally Retarded (1971) and the UN Declaration on the Rights of Disabled Persons (1975). In more detail, the recommendations for people with autism are:

1. the right to lead an independent life, to be carried out according to their means

2. the right to a diagnosis and an accurate clinical assessment, comprehensible and free from preconceptions

3. the right to receive an appropriate education, freely accessible to all

4. the right for them (or their representatives) to participate in all decisions about their future

5. the right to accessible and adequate housing

6. the right to have all appropriate means, help and the responsibility necessary to lead a fully productive life with dignity and independence

7. the right to receive a pension or a salary sufficient to provide food, clothing, shelter and all other vital necessities

8. the right to participate, as much as possible, in the development and management of services that take care of their welfare

9. the right to benefit from the advice and care appropriate to their mental and physical health and for their spiritual life

10. the right to an education corresponding to their desires and meaningful employment without discrimination and without preconceived ideas

11. the right to benefit from means of transport and freedom of movement

12. the right of access to culture, recreation and leisure activities.

\section{Italian Legislation Concerning People with Autism}

The Legge quadro n. 104 per l'assistenza, l'integrazione sociale e $i$ diritti delle persone handicappate of 1992 (Framework law no. 104 for the assistance, social integration and rights of persons with disabilities of 5 February 1992) includes 'full

\footnotetext{
${ }^{37}$ The families who are not receiving adequate services do not engage in any legal action, as Autism-Europe pointed out, as Poland admits the presentation of a judicial appeal against the administration only in the event that friendly appeals to the same administration have failed.
} 
respect of human dignity and human rights concerning the freedom and independence of the handicapped person' among its aims ${ }^{38}$ and it promotes their full integration in the family, at work and in society, and is an extremely important reference point for the purposes of recognition and the basic legislation for the theme of this paper. In fact, as it is a framework law, it does not recommend particular action with reference to specific diseases, but general principles to apply to all people with disabilities who need to find timely implementation for the particular circumstances of individual cases. The exceptional reach of the law, in fact, constitutes, inter alia, the legitimacy of the principle of social integration. ${ }^{39}$

This framework legislation was subsequently recalled and further recognized in the Act no. 67 of 1 March 2006, Misure per la tutela giudiziaria delle persone con disabilità vittime di discriminazioni (Measures for the judicial tutelage of persons with disabilities who are victims of discrimination). This promotes the full implementation of the principle of equal treatment and equal opportunities for people with disabilities (referred to in Article 3 of the Law of 5 February 1992, no. 104), so as to ensure the full enjoyment of their civil, political, economic and social rights. ${ }^{40}$ Between May 2007 and January 2008, the aforementioned Tavolo nazionale di lavoro sull'autismo (National Working Table on Autism) ${ }^{41}$ was established on the recommendation of the Minister of Health, who, with the help of a special scientific committee and specific study groups, addressed issues that concerned, in particular, the spread of autism and its causes, as well as problems at intake, structural services, the effectiveness of treatments, the training of workers and the need for scientific research.

In this forum, ${ }^{42}$ full convergence of the opinions of the scientific committee was expressed regarding some aspects concerning people with autism in adulthood. It was stated, inter alia, that 'programmes for the care and protection of persons with autistic disorders require a paradigm shift in the approach to disability by pivoting on the person, their rights, their needs and their potential. This approach entails a general policy of services respecting the wholeness of the person with autism and his plans for life and those of his family; this overall policy must be developed throughout the whole lives of people with autism. In addition, the protection of health, access to learning and social inclusion must be guaranteed to every person regardless of the nature and severity of their disability or age'. Still more relevant to the purposes of this research, as will be underlined in the following, is namely: 'The need to spread the awareness that autism is a problem that affects the entire life

\footnotetext{
${ }^{38}$ Article 1, para a.

${ }^{39}$ Affirms and protects subjective right to the full development of the human potential of people with disabilities, a right which cannot be limited by obstacles or impediments of any kind, which may be removed at the initiative of the State.

${ }^{40}$ Law no. 67 of 1 March 2006, Article 1.

${ }^{41}$ It was composed of members of the most representative associations in the country, experts, technicians from the regions, the Istituto Superiore di Sanità (National Institute of Health), scientific societies and professional associations for rehabilitation.

${ }^{42}$ This refers to the final report of the Tavolo nazionale di lavoro sull'autismo (National Working Table on Autism), January 2008.
} 
cycle. More than one research project, conducted in various regions, signal the numerical collapse of the diagnoses of autism after the age of 18. The situation of adults with autism is strongly affected by the severe shortage of services, planning and programming for the future which too often produce an exorbitant burden for families, with the risk of loss of autonomy and skills laboriously achieved, pharmacological abuse to overcome the lack of appropriate treatment techniques or the proper organization of contexts and habitats due to strongly segregating, purely custodial and restrictive institutionalization. There is therefore a need to take responsibility for the whole lifecycle of people with autism, from childhood to adulthood and old age'. ${ }^{43}$

The considerations outlined by the Tavolo nazionale di lavoro sull'autismo (National Working Table on Autism) demonstrate that Autism Spectrum Disorders are more common than previously thought and, above all, that there is an urgent need and priority for an appropriate integrated therapeutic and rehabilitative training plan, able to provide assistance to adults, with a view to inclusion in society and the world of work. One very interesting proposal originating from the work of the National working party is to design and test a plan of measures for a 'national action system', defined as the Progetto Nazionale Autismo (National Autism Project). ${ }^{44}$ The Ministry of Health accompanied the activities of the working party with initiatives for making connections, which have already led to very positive results, indicating the importance of stabilizing links of dialogue with the Coordinamento delle Regioni (Regional Coordination) and the Istituto Superiore di Sanità (National Institute of Health). ${ }^{45}$

\footnotetext{
${ }^{43}$ Ibid.

${ }^{44}$ Among their goals, the main ones are summarized as: ' $[\ldots .$.$] the Ministry of Health will develop,$ in collaboration with the Regional Authorities, a working plan to address providing operating instructions for the homogeneous programming, implementation and monitoring of activities for children and adults with autism, to improve the performance of network services, to promote links and coordination between all the areas affected; [...] To provide a concrete answer for the whole lifecycle of patients, directing the integration of health, educational and social services in their mutual relations and connections with initiatives from Family Associations, private groups and private social groups'. See Relazione finale del Tavolo nazionale di lavoro sulle problematiche dell'autismo (Final Report of the National Working Table on Autism), January 2008.

45 'As far as relationships with the Regional Administrations are concerned, it should be noted that firstly the link was activated through the request forwarded to the Gruppo Interregionale sulla Salute Mentale e Assistenza Psichiatrica Interregionale (Inter-regional Group on Mental Health and Inter-regional Psychiatric Care) to join with their two representatives in the National working party on autism. Please note that the Interregional Group had indicated two child psychiatrists appointed by the Piedmont Region and the Region of Sicily. [...]. Moreover, work is being carried out to insert needs for programming in the field of autism in the Piano Strategico Salute Mentale (Strategic Mental Health Plan), which is being developed through integration between the Ministry and the Interregional Group. In the context of these activities of linking and joint programming, between the Ministry and Regional Co-ordination it was asserted that each region draw up a working plan for autism and that these plans be envisaged as connecting and sharing some basic programming principles. For this purpose, particular significance could be given to the dissemination and application of the Linee Guida sull'Autismo elaborate dalla Società Italiana di Neuropsichiatria dell'Infanzia e dell'Adolescenza SINPIA (Guidelines developed by the Autism Society of Italian Childhood and Adolescence) which, in some regions have already been implemented and used in their programme planning' (Ibid).
} 
In the Linee di indirizzo per la promozione ed il miglioramento della qualità e dell'appropriatezza degli interventi assistenziali nei disturbi pervasivi dello sviluppo (DPS), con particolare riferimento ai disturbi dello spettro autistico (Guidelines for the promotion and improvement of the quality and appropriateness of care measures in Pervasive Developmental Disorders (PDDs), with particular reference to autism spectrum disorders) ${ }^{46}$ there is a very strong awareness of the complexity of the phenomenon of autism and its implications within the family and society. It is equally important to recall that they underline urgent and concrete commitment on the part of national institutions and central and regional authorities in close cooperation with family associations, which in Italy are an essential and tangible reality, for the protection of the rights of people with autism at all stages of life. ${ }^{47}$ The document urges making essential levels of assistance (the so called Livelli essenziali di assistenza 'LEA') accessible and homogeneously diffuse in all regions, so that they are part of a network of coordinated measures 'ensuring a specific interdisciplinary multi-professional approach, essential for dealing with the complexity and heterogeneity of autistic syndromes' ${ }^{48}$ Thus, the stress is on the importance of activating health-planning initiatives as well as achieving inclusive education and social development at a regional level.

At present, there is a small number of experiments in this direction, limited to a quarter of the country, and the overall picture shows a lack of consistency of approach to the management of the different conditions of persons with autism. However, for the purposes of this paper, it is important to note that, in the guidelines mentioned above, the areas of Health, Social, Education and Labour are encouraged to link up across policy areas and to promote, among other things:

\footnotetext{
${ }^{46}$ Document approved as an agreement in Joint Conference, 22 November 2012.

${ }^{47}$ Consider that in a recent British study (2007), Ganz calculated that each individual with autism cost about $\$ 3.2$ million to society and for families throughout their life. A cost which includes the loss of productivity and necessary assistance (approximately $59.3 \%$ of resources is due to lost productivity and other indirect costs). Similar findings are to be seen in the early results of a study currently underway at ISS (National Institute of Health), as part of the Primo programma nazionale di ricerca strategica in età evolutiva (First National Programme for Strategic Research in developmental age), in order to quantify and characterize the burden of suffering and the needs of families with a child with an autism spectrum disorder and the demographic, socio-economic and welfare factors associated with it. A recent view on the needs of families with a member with autism is also offered by the first results of the research Centralità della persona e della famiglia (The centrality of the person and the family), Serono Foundation and Angsa performed by Censis, tabled in Parliament, 22 November 2011'. Linee di indirizzo per la promozione ed il miglioramento della qualità e dell'appropriatezza degli interventi assistenziali nei Disturbi pervasivi dello sviluppo (DPS), con particolare riferimento ai Disturbi dello spettro autistico (Guidelines for the promotion and improvement of the quality and appropriateness of care interventions in Pervasive Developmental Disorders (PDDs), with particular reference to Autism Spectrum Disorders), Ministry of Health, 22 November 2012.

${ }^{48}$ Ibid.
} 
a) multidimensional assessment combining health, education and social aspects operating as a Multidimensional Assessment Unit of skills and needs and the identification of an operational profile;

b) activation, even after school age, of a case manager who is responsible for the execution of the PAI (Patient Assessment Instrument);

c) liaison and coordination of different measures and different services in order to ensure adequate continuity for the entire life cycle of the person;

d) enhancement of daycare facilities and activities for social inclusion, and inclusion in the world of work for adults with autism

e) expansion of residential facilities for people with pervasive developmental disorders in adulthood, aimed at the acquisition of a greater autonomy and/or assistance to the family.

By means of the 'Ratification and implementation of the UN Convention on the Rights of Persons with Disabilities', (Act no. 18, 3 March 2009), Italy ratified the 'UN Convention on the Rights of Persons with Disabilities' and also its Optional Protocol, signed in New York on December 13 2006. In addition, the Act established the Osservatorio nazionale sulla condizione delle persone con disabilità (National Observatory on the Status of persons with Disabilities) (Article 3), chaired by the Minister of Labour, Health and Social Policy. The Observatory was given tasks intended to ensure the promotion of the implementation of the Convention; it was also entrusted with collecting statistics relating to the situation of people with disabilities, together with reference to different situations in the country (Article 3, para 5, letter c), the preparation of a biennial programme of action for the promotion of rights to integration (Article 3, para 5, letter b), and the preparation of a report on the implementation of policies on disability, pursuant to Article 4 of Law no. 104/1992 (Article 3, para 5, d).

\section{Protection of the Rights of People with Autism in Italian Regional Laws}

On 7 October 2014, the Marche region was the first among the Italian regions to have approved an organic law ${ }^{49}$ on autism, whose purpose, as explained in the explanatory report, is to 'promote the well-being and social inclusion of people with autism spectrum disorders. In detail, through an integrated network of services it would guarantee diagnostic, therapeutic, and rehabilitative care for children and adults with autism spectrum disorders. In addition, the social integration, education and employment of these individuals will be pursued, recognizing the crucial role

\footnotetext{
${ }^{49}$ Referring to Draft Law no. 427 of 21 July 2014, Disposizioni in materia di disturbi dello spettro autistico (Provisions for autism spectrum disorders).
} 
of the family as an active part in processing and implementing the overall project for life'.

In Italy, there are other regions which have demonstrated their sensitivity towards the problem of higher education and professional training for individuals with autism, in particular, and who have developed guidelines that have sometimes anticipated the content of the results of the Tavolo tecnico di lavoro nazionale (Technical board of national labour), such as, for example, Emilia Romagna. ${ }^{50}$ However, there are regions which, to date, in light of the abovementioned 'Guidelines for the promotion and improvement in the quality of the appropriateness of care measures in Pervasive Developmental Disorders (PDDs), with particular reference to autism spectrum disorders', are struggling to establish specific lines of operation. 'The current regional services for the problems of children and adolescents are affected by differences in the models and in the times for their planning and establishment that have been pursued by each Region. In recent decades, regional programmes seem to have moved towards addressing neurological, psychiatric and neuropsychological issues in childhood and adolescence by basically following two paths: in some regions, services are directed to the field of 'mother-child' health, in others towards psychiatric services for adults and thus to the Dipartimenti di Salute Mentale (Departments of Mental Health). Other regions have not yet precisely defined the organization and placement of services. However, in our legislative scenario, the coexistence of two Planning Objectives (POs) which address this issue should be considered. The PO Tutela della salute mentale 1998-2000 (Protection of mental health 1998-2000) states that the organizational experience of mental health services for the adult population suggests that mental health activities dedicated to developmental age (child and adolescent) can be carried out on a departmental model, both structurally and technically functional, in a single direction, which ensures the unity of operations, continuity of care and the functional link between all departments involved in the protection of mental health, even when placed in different operational structures'. ${ }^{51}$

However, examining textual indications and proposals for legislative action programmes the necessary uniformity is not ensured, and also from the analysis of the guidelines for autism, emanating from different Italian regions (Abruzzo, Campania, Emilia Romagna, the Autonomous Province of Bolzano, to name but a few), ${ }^{52}$ a uniform way in which to draw a univocal level of performance from their

\footnotetext{
${ }^{50}$ The data are taken from the records of workshop Autismo che fare? (What can we do about Autism?) Emilia Romagna, and comparing other Italian regions on the models of operation. Bologna, 17 January 2007.

${ }^{51}$ Decision by the regional council, 3 September 2008, no. 1384, Linee d'indirizzo per la salute mentale (Operational guidelines for mental health), excerpt.

${ }^{52}$ La Società Italiana di Neuropsichiatria dell'Infanzia e dell'Adolescenza (The Italian Society of Neuropsychiatry in Childhood and Adolescence) has taken steps to issue Linee Guida per l'Autismo. Raccomandazioni tecniche-operative per i servizi di neuropsichiatria dell'età evolutiva (Guidelines for Autism. Technical and operational recommendations for the services of developmental neuropsychiatry).
} 
various situations does not emerge. This causes, on a regional level, a considerable gap between the levels of care exercised by the regions that generates, in turn, differentiation between the levels of performance, in apparent conflict with the principles of the formal and real equality of these constitutionally guaranteed individuals. So, from the picture that emerges between the different regional situations, there is no integrated coordination of issues that affects people with autism spectrum disorders.

The proposals of some Italian regions are summarised below.

\subsection{Draft Laws and Regional Regulatory Developments in the Theme of Autism}

\subsubsection{The Region of Basilicata}

Regional legislation identifies the Servizi di Neuropsichiatria Infantile (Child Neuropsychiatry Services), which are part of a single internal department of regional significance (DINPEE), divided into a single regional operating hospital unit, local operating units in each ASL (local health authority), and protected facilities for daycare and residential rehabilitation and recovery throughout the region. The plan for PSSR 2010-2012 envisages the creation of a 'regional centre of reference for infantile autism' and, by the second year of the plan, the development of a 'Day Centre for Autism' for each ASL.

\subsubsection{The Region of Calabria}

Calabria has not adopted specific rules relating to autism, but it is included as one of the diseases treated by the Dipartimento della Salute Mentale (Department of Mental Health). Through the guidelines and the organization of health activities, the establishment of centres for the prevention, treatment and rehabilitation of specific disorders, including autism is envisaged. Regional regulation no. 13 of 2009 , relating to regulations and manuals for the accreditation of the regional health system, identifies organizational, structural and technological centres for extensive daycare rehabilitation for autism outside the hospital. These centres carry out rehabilitation daycare activities for adults, while for children with autism or similar disorders at different levels of gravity, which may require intensive and/or extensive care in the nature of rehabilitation and social rehabilitation, the aim is to develop their potential and their acquisition of the greatest independence possible. 


\subsubsection{The Region of Campania}

The Campania region has adopted specific Linee guida per il trattamento del disturbo dello spettro autistico (Guidelines for the treatment of autism spectrum disorder), ${ }^{53}$ with particular reference to the pediatric age (in 2003 and 2009), in full harmony with SINPIA recommendations and the document produced by the Tavolo nazionale di lavoro sull'autismo (National Working Table on Autism), 2008. Nevertheless, there are no specific rules relating to adults and their inclusion in an employment context, but these can be referred to in the discussion on the decisions prepared by the Department of Mental Health. The Autismo-University project, prepared jointly by the Centri Servizi per la Disabilità (Centres for Disability Services) of the Universities of Bologna, Catania and Naples, with the collaboration of associations ANGSA Campania and Autism Aid Onlus, is also worth mentioning. This school-university project defines learning objectives related to training, in strict accordance with the Dublin descriptors, as regarding the expected knowledge, skills and abilities and/or transferable skills in life and work contexts. In more detail, it is designed to provide students with Autism Spectrum Disorders and their families with tools to ensure a more conscious relationship with daily life, also from the perspective of improving and rationalizing interactions between educational institutions, local government, associations and families. ${ }^{54}$

\subsubsection{The Region of Emilia Romagna}

Emilia Romagna offers generous legislation for people with autism, including the Programma Regionale Integrato per l'assistenza alle persone con disturbo dello spettro autistico-ASD (Integrated Regional Programme for Assistance to People with Autism Spectrum Disorders-ASD) (PRI-A), and a support network of more articulated levels. The overall objective of the PRI-A project is to provide relevant hubs to which interested parties in the province can refer, to structure integrated pathways of the care system; this project involves an organization in a 'hub' and 'spoice' network model (reference centres covering large areas are 'hubs' and connected centres are 'spoices'). There are not, however, significant and explicit references to the condition of adults with autism, in view of ongoing education and vocational training.

\subsubsection{The Region of Friuli Venezia Giulia}

Friuli Venezia Giulia has addressed issues related to taking integrated charge of people with disabilities, who include individuals with Autism Spectrum Disorders,

\footnotetext{
${ }^{53}$ No. 21 of 2011, compiled by the Istituto Superiore della Sanità (National Institute of Health).

${ }^{54}$ National Project MIUR-CNUD 2009-2010. The national coordinator is Prof. Andrea Canevaro.
} 
and placing them in the context of the regional social and health plan 2010-2012. ${ }^{55}$ At this stage, the network of services works closely with the voluntary and third sector network, in particular with the Fondazione Bambini e Autismo ONLUS (Children and Autism Foundation NPO), a private non-profit institution, based in Pordenone, accredited and part of the Regional health care service, which provides network services for autism from infancy to adulthood. The venture includes building a diagnostic centre, a rehabilitation centre, a daycare centre and a work centre for adults. The main strategy, in a wider regional socio-health context, is to build a path of access, taking care of people with disabilities with a view towards a different relationship between the citizen and the welfare system. 'Taking integrated charge' is understood as the set of measures (health and social services firstly, but also educational, active labour market policies and the education system) and the legal and organizational conditions which, for the entire life span of a person with disabilities, guarantees a constant and comprehensive assessment of their operation resulting from the interaction between the person and the environment in which he lives. From this perspective, the concrete realization of regional health and social welfare reform requires systematic and consistent commitment necessitating adjustment and modifications in organizational and managerial legislation.

\subsubsection{The Region of Lazio}

The Lazio region approved the Autismo ed Educazione Speciale (Autism and Special Education) project $^{56}$ with the intention of engaging in a continuous exchange of information and direct communication between institutions, scientific researchers and users. With Regional Law no. 2 of $2009,{ }^{57}$ the Centro di accesso unico alla disabilità (Centre of single access to disability) was established, in order to guarantee that all citizens had access to the necessary information, in terms of assistance and guidance, and to ensure efficient management of the treatments and services for people with disabilities and their families. The centre also promotes, supports and coordinates actions and services within a single integrated health and social care access point. The region, on the basis of the service network, has also allocated some resources for public and non-profit organizations whose activities are aimed at people with autism; in the province of Rome, in particular, there are specific plans for patients with disorders of the autism spectrum. In contrast, however, there is no indication that there will be widespread and significant

\footnotetext{
${ }^{55}$ The objective of the plan is to obtain integrated control with different instruments, the first of which is the adoption of a common instrument for the multidimensional assessment of need and the definition of a personalized care plan, such as the ICF biopsychosocial model (International Classification of Functioning, Disability and Health) World Health Organization (2001).

${ }^{56}$ Regional Resolution no. 924, 26 October 2006. Innovative projects aimed at improving the lives of families who take care of autistic people at home.

${ }^{57}$ Founding of the Centro di accesso unico alla disabilità (CAUD).
} 
legislative initiatives in favour of adults with autism, relating to higher education and vocational training.

\subsubsection{The Region of Liguria}

The Liguria region is very active in the field of autism; in fact it has promulgated, over a long period, several projects in collaboration with specialized centres and Associazioni dei familiari (family associations). ${ }^{58}$ The region approved specific guidelines for autism, especially in Resolution no. 1555, 12 December 2004, Approvazione indirizzi in materia di autismo (Approval of guidelines on autism), adopted on the application of the 3-year plan for social services and community health, which defined the network of services for childhood, adolescence and adulthood. In addition, the Gruppo Regionale Autismo (Regional Group for Autism) was established, through which detailed regulations for the transition in care, from adolescence to adulthood were laid down. ${ }^{59}$ In 2009 , Liguria approved a regional agreement ${ }^{60}$ aimed at the adoption and implementation of the Linee di Indirizzo Nazionali per la Salute Mentale (National Guidelines for Mental Health) which include, among other points, the implementation of treatment programmes in the area of autistic spectrum disorders, in accordance with the final document of the Tavolo nazionale di lavoro sull'autismo (National Working Table on Autism), $2008^{61}$

\footnotetext{
${ }^{58}$ More proactive synergies were activated, in particular with the association ANGSA Liguria and the GROUP ASPERGER-Liguria.

${ }^{59}$ Precisely due to this delicate transition, it is expected that the maternal-infant sector (NOAC), which was in charge of the patient, report the case to the district of expertise. In the individual ASLs (local health authorities), adult patients with autism are supported by the Unità operativa assistenza disabili (Operational Unit Support Centre for the Disabled) (UOAD).

${ }^{60}$ Regional Resolution no. 739.

${ }^{61}$ Among other regulatory guidance in the region, there is: the Decree of 17 October 2002, no. 2147, Progetto Autonomia per Minori e Giovani Adulti con Problemi Relazionali. (Autonomy Project for Children and Young Adults with Relationship Problems), a regional contribution to the setting up of ANGSA-Liguria-Associazione Nazionale Genitori Soggetti Autistici (National Association of Parents of Autistic Subjects), Regional Law no. 15/2000, Norme ed Interventi in Materia di Diritto all 'Istruzione e alla Formazione (Rules and Measures relating to the Right to Education and Training) (Chapter II: Regional Measures), Decree of 7 July 2006, no. 2106 Progetto di Interesse Regionale in Materia di Autismo (Project of Regional Interest in the Field of Autism), Regional Council Resolution, 27 October 2006, no. 1118, Soggetti Autistici per una Presa in Carico Integrata (Integrated Care for Autistic Subjects) jointly between the Genoese ASL 3 and the Istituto David Chiossone.
} 


\subsubsection{The Region of Lombardy}

The Lombardy Region has approved, over the years, various projects for autism; in 1996, it activated the Osservatorio autismo della Regione Lombardia (Autism Observatory of the Lombardy Region) and since 1998, experimental points of convergence for autism have been put into action. In addition, in resolution no. 8/6861, 19 March 2008, the Linee di indirizzo regionale per la neuropsichiatria dell'infanzia e dell'adolescenza (Regional Guidelines for Neuropsychiatry in Childhood and Adolescence) were approved in the realisation of the PSSR 2007-2009. In 2008 , in view of the results of the research La Famiglia davanti all'autismo (The Family Facing Autism) in 2005, the Direzione regionale famiglia e solidarietà sociale (Regional Directorate of Family and Social Solidarity) launched a tender for the financing of 3-year projects on autism. The Lombardy Region also approved a Bando per la promozione di iniziative sperimentali per sviluppare una rete di interventi e opportunità a favore delle persone autistiche e delle loro famiglie (Call for the Promotion of Experimental Initiatives to Develop a Network of Measures and Opportunities for People with Autism and their Families), ${ }^{62}$ which aims, in fact, to implement policies in support of families, financing projects through local partnerships, also with a view to the possibility of increasing existing connections between different parts of the system of services for people with autism and their families. As a result of this announcement, the region has financed three projects carried out in respective ASLs (local health authorities) with the involvement, for about 2 years, of more than 300 families with autistic children aged 3-21 years. $^{63}$

\subsubsection{The Region of Marche}

With the approval of the Regional Health Plan 2003-2006 and the Regional Law no. 13, 20th June 2003 for the reorganization of the health service, some elements for social and health integration of great importance were introduced into the regional system of Marche. ${ }^{64}$ Among the most significant of these is the L'Autismo nella regione Marche-verso un progetto di vita (Autism in the Marche regiontowards a life plan), a project which has put into action important expertise in support of family members.

\footnotetext{
${ }^{62}$ Regional Resolution no. 6635, 20 February 2008.

${ }^{63}$ ORMA project, Organizzazione della Rete e del Modello di Sostegno per l'Autismo nella ASL di Cremona, (Organization of the Network and the Support Model for Autism in the Local Health Authority of Cremona), Networking: the contribution of all towards the integration and continuity of measures for people with autism and their families in the ASL (Local health Authority) MonzaBrianza, Rete Autismo (Autism Network) at ASL Milano 1.

${ }^{64}$ The Marche Region, as mentioned above, is the first in Italy to have approved, on 7 October 2014, a specific regional law on autism.
} 


\subsubsection{The Region of Molise}

In the Region of Molise there is no specific legislation on autism; the main legislative reference is Regional Law no. 30, $2002^{65}$ and the relevant implementing regulation no. 1, 2004. The Regional Health Plan 2008-2010 envisages the empowerment of services for mental health care, especially the construction of residential medium and low complexity care: daycare and outpatient and home care, as well as activities for social and labour inclusion. It should be emphasized that the University of Molise has started, with Aurora Aid NPO, scientific collaboration and support for university education, relating to the theme of autism.

\subsubsection{The Autonomous Province of Bolzano}

In the Autonomous Province of Bolzano guidelines for autism have been adopted in the German language, which, however, have not been included in a Act. References to legislation, in fact, relate to the tutelage of mental health. In Alto Adige, people with autism can rely on an extensive network of services in all four districts that comprises the only health authority, providing care and support to both individuals with autism and their families. There are, in addition, some active projects in conjunction with the University of Bolzano, which has an established tradition of inclusive education.

\subsubsection{The Autonomous Province of Trento}

The Autonomous Province of Trento has set up specific centres for autism, which operate in close collaboration with families and the school. Thanks to the directives of the provincial health services for the provision of additional health benefits for the years 2007-2009, the Province has envisaged a financial contribution, by way of contributions to the cost of rehabilitation, for the benefit of patients with autism, childhood psychosis or cerebral palsy.

\subsubsection{The Region of Puglia}

In Puglia the main point of reference is the Regional Health Plan for 2008-2010 66 which identifies new targets for the prevention and treatment of disabilities, to be achieved through an integrated network of health and social workers, families and the school. The Plan highlights the lack of social and rehabilitative structures for some pathologies, among which is autism. ${ }^{67}$

\footnotetext{
${ }^{65}$ Implementing Regulation, pursuant to Article 13.

${ }^{66}$ Regional Law no. 23, 19 September 2008.

${ }^{67}$ However, some centres of excellence operate in the region, such as: the Centro Nostra Famiglia (Our Family Centre) in Ostuni, the Centro di Riabilitazione Padre Pio (Father Pio Rehabilitation Centre) in San Giovanni Rotondo, the Osmairm in Laterza, and the Centro di Riabilitazione dei Padri Trinitari (Rehabilitation Centre of the Trinitarian Fathers) in Gagliano del Capo.
} 


\subsubsection{The Region of Sardinia}

With Regional Resolution (DGR) no. 44/10 of 31 October 2007, the Programma straordinario di interventi per l'autismo e gli altri disturbi pervasivi dello sviluppo (Extraordinary Programme of Measures for Autism and other Pervasive Developmental Disorders) was approved, underling the measures in the Piano Regionale dei Servizi Sanitari 2006-2008 per la Neuropsichiatria Infantile e dell'Adolescenza (NPIA) (Regional Plan of Health Services from 2006 to 2008 for Child and Adolescent Neuropsychiatry). This special programme is aimed at overcoming the current organizational, logistical and training deficiencies in the specific field of autism and pervasive developmental disorders, and covers several areas, including the reorganization of services for autism and other pervasive developmental disorders, as well as including and integrating the activities of the Centro per l'assistenza a bambini e adolescenti con disturbi pervasivi dello sviluppo (Centre for the care of children and adolescents with pervasive developmental disorders) ${ }^{68}$ within the network of NPIA services, strengthening the supply of local services and NPIA hospitals and training the operators involved in the network of services.

\subsubsection{The Region of Sicily}

In Sicily, on 22 December 2005, a specific rule of law was promulgated stating that: 'The Regional Councilor of Health is authorized to issue a decree, within one hundred and eighty days from the date of publication of this Act, for a uniform regional programme for autism. This decree envisages that every local public health unit company of the Sicilian Region activates a centre for autism and pervasive developmental disorders ${ }^{9}{ }^{69}$ In 2007 , guidelines for autism were published, with the aim of strengthening the currently patchy network of services in each ASL. However, to date, in Sicily there remains a shortage of specialist services, including dedicated services, as the document guidelines have only been partly realized. In fact, even if regional centres of excellence and good services operate, there are not enough to cover their needs. ${ }^{70}$ An interesting activity has been realised by the Fondazione siciliana per l'autismo (Sicilian Foundation for Autism) (FSA),

\footnotetext{
${ }^{68}$ Regional Resolution no. 39/61, 10 December 2002. Special action programme for autism and other pervasive developmental disorders.

${ }^{69}$ Article 25(8).

${ }^{70}$ For example, IRCCS Maria Santissima di Troina, NPIA and territorial ASLs have promoted and prepared Units in each District, coordination with the Hospital, involvement of associations of parents and the school (with specific training of support teachers), courses for the adoption of an observation method for suspected diagnosis for paediatricians, and learning skills training and coherent taking charge, according to TEACCH and TED methodologies.
} 
founded in June 2007 by a group of families, headed by ANGSA-Sicilia, who promoted a project pivoting on the development of the person with autism and the protection of his rights, including his right to an adult life.

\subsubsection{The Region of Tuscany}

The Regional Health Plan 2008-2010 includes specific goals for improving the network to ensure, in particular, a passage between the Unità Funzionali Salute Mentale Infanzia Adolescenza (Mental Health in Childhood and Adolescence Functional Units) and those for adults. In implementing the Plan, the region has adopted guidelines for early diagnosis and taking charge of multi-spectrum autistic disorders, ${ }^{71}$ governing the system of services, as well as through the establishment of semi-residential (day care centres) and residential buildings, such as:

a) day centres, which must ensure qualified rehabilitation to accommodate the disease at different stages of life;

b) residential structures, articulated in several modules, which ensure the continuity of the care pathway, both for long and for limited periods of time, in relation to the clinical situation and the needs of the family;

c) highly specialized referral centres, supporting interdisciplinary teams, for children, adolescents and adults.

Therefore, the integrated network of services includes highly specialized reference centres, interdisciplinary business work groups and organizations of mutual aid. The region promotes various projects and initiatives on issues of assistance to people with autistic spectrum disorders (ASD). One, in particular, the Osservatorio Regionale Autismo (Regional Autism Observatory) ${ }^{72}$ is active with scientific representatives and experts to monitor the management of the integrated network services.

\subsubsection{The Region of Umbria}

Umbria has developed an interesting and detailed plan of action by means of the Progetto per la promozione della salute dei minori affetti da autismo (Project for the promotion of the health of children affected by autism). In 2009, moreover, a Centro di Riferimento regionale per l'autismo (Regional Reference Centre for Autism), was established by the Regional Health Plan with the task, among others, to promote a trial on the use of innovative strategies to ensure better continuity of the care extended at the age of adolescence and adulthood, actively supporting social inclusion and appropriate forms of protected residence and job placement. In

\footnotetext{
${ }^{71}$ Regional Board Resolution no. 1066, 3 December 2008.

${ }^{72}$ Regional Resolution no. 6904, 29 December 2009.
} 
this local context, the ANGSA $^{73}$ Association, founded on the stimulus of some parents who in 1985 wanted to give a future to people affected by autism, assumes a proactive decisive importance in supporting families. Even today, the Association holds significant importance in the region and throughout Italy, especially since, in 1989, it became part of Autism-Europe for its exchange of good practices of care and integration on an international scale. The Regional Social Plan also envisages SAL, services aimed at promoting tools and pathways (apprenticeship training, grants for work, ILSA, oriented in favour of vulnerable groups). The Dipartimento di salute mentale (Department of Mental Health) (DSM), together with the Deliberazione di Giunta Regionale (Regional Council Deliberation) no. 21, 12 January 2005, in particular, have developed 'training programmes and job placement in support of therapeutic pathways'. However, even though the Umbrian experience has demonstrated an increasing use of specific tools in the work area, it is very patchy and unstable in the face of ever-increasing difficulty in employment.

\subsubsection{The Region of Valle d'Aosta}

The Valle d'Aosta has no specific legislation on autism, but the care network is framed within the operating model of assistance for mental health care, Piano Regionale per la Salute e il Benessere Sociale 2006-2008 (Regional Plan for Health

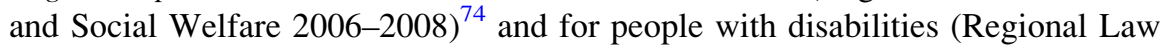
no. 14, 18 April 2008). The Plan recognizes the function of mutual help groups between family members, patients and social cooperatives, for the purpose of employment. The Regional Law cited above is significant as it concerns an integrated system of measures and services for people with disabilities defining a Progetto individuale per la persona con disabilità (Individual Project for the Person with a Disability); this includes, in addition to a diagnostic and functional assessment, the performance of care and treatment and rehabilitation, as well as education, instruction, training and job placement in the perspective of social integration. ${ }^{75}$ The region recognizes the modality for certifying skills according to the school curriculum as a means of correlation and connection between the worlds of education and work; it also supports attendance on routes to university

\footnotetext{
${ }^{73}$ The ANGSA Umbria Region was established in 2000.

${ }^{74}$ The Plan is responsible, together with the municipalities, for health and social integration and states that the services have been established for the protection of mental health, an operational model for regional assistance for the mentally ill, based in the area, albeit at different degrees of fulfilment.

${ }^{75}$ The Law also envisages that the region promotes the education process, both scholastic and training, covering all phases of the life of the person with disabilities from birth up to the age of the 64 years of age.
} 
education by promoting specific initiatives for education ${ }^{76}$ in order to foster strategies to support lifelong learning.

\subsubsection{The Region of Veneto}

The Region of Veneto is largely characterized by its legislation to protect the rights of persons with disabilities, promoting measures in favour of those with autism, programming initiatives, research projects and training programmes, carried out in collaboration between the region, universities, non-profit organizations, health-care professionals and social workers. The Piani Locali della Disabilità (Local Disability Plans) trace routes of treatment with home care and residential facilities, based on multidimensional assessment, by means of the Scheda di valutazione per le persone disabili (Assessment Form for People with Disabilities) (S.Va.M.Di.). ${ }^{77}$ The Veneto Region, with DGR no. 3792, 2 December 2008 Approvazione progetti di sostegno al sistema di offerta per persone non autosufficienti e disabili (Approval of projects that support the supply system for dependent persons and the disabled), supports the project Centro educativo pomeridiano per il trattamento dei disturbi pervasivi dello sviluppo di tipo autistico (Afternoon education centre for the treatment of pervasive developmental disorders in the autistic spectrum). ${ }^{78}$ Moreover, since 2006, the regional government annually approves and assigns resources for the creation of innovative structures for disability, including centres for autism. ${ }^{79}$ The objective of these initiatives is to enhance services for people with disabilities and to promote opportunities to improve inclusion in education and employment. For people with autism, in particular, there is a need to implement the network of accessible specialist services, evenly spread throughout Veneto, and a need can be seen for stronger links between health, social and education areas.

\section{From Legislation to Good Practice: National and European Autism Projects}

In the individual Italian regions, there are several important specific initiatives of different nature and content aimed at achieving systematic action plans in relation to autism. 'We have to clarify, however, that the picture that emerges is in no way

\footnotetext{
${ }^{76}$ They are presented by the Centro Territoriale Permanente di Istruzione e Formazione in Età Adulta (Permanent Territorial Centre for Education and Training in Adulthood) (CTP), established by decree by the Superintendent of Education of the Autonomous Region of Valle d'Aosta, 21 February 2005, no. 7438.

${ }^{77}$ The Assessment Form was approved by Regional Resolution no. 331, 13 February 2007. Multidimensional assessment of persons with disabilities according to the ICF, subsequently integrated into Regional Resolution no. 2575, 4 August 2009.

${ }^{78}$ This project was presented by the company ULSS no. 10 and envisages the implementation of an afternoon workshop for children with autism.

${ }^{79}$ Regional Resolution no. 2333, 28 July 2009.
} 
homogeneous regarding both the general profile, referring to the whole country, and local measures that cannot be assimilated with each other from the point of view of content'. 80

In the Marche Region, the Sotto-Progetto per l'istituzione di servizi per adolescenti ed adulti con disturbi autistici (Sub-Project for the establishment of services for adolescents and adults with autistic disorders) ${ }^{81}$ aims to promote the social integration of adolescents and adults with autism and focuses on adapting existing socio-educational day centres ${ }^{82}$ and youth groups. ${ }^{83}$ The project consists of the following points: characteristics of services for adolescents and adults, methodology of operation, training personnel, regional initiatives, the stages of implementation of the project, assessment and cost analysis. The prospect is to facilitate, through the implementation of socio-educational daycare centres and youth groups, opportunities to experience as normally as possible, a social life for individuals with autism, in a proper interaction with a real-life environment.

These centres are open at least $7 \mathrm{~h}$ a day, at least 5 days a week, 11 months a year. Moreover, a Management Committee with political, technical and users' families representation has been established, and a one-to-one relationship between social worker and user is guaranteed. In the project, the specific characteristics required of

${ }^{80}$ Giofrè (2010), p. 55.
${ }^{81}$ This is an integral part of the project L'autismo nella regione Marche-verso un progetto di vita (Autism in the Marche region-towards a life project) (Bollettino ufficiale regionale no. 121, 29 October 2002). The coordination group for the project consists of: Dr. Piero Feliciotti, psychiatrist for ASL no. 9 of Macerata (representing the technical-professional area), Prof. Lucio Cottini, Lecturer in Special Education at the University of Urbino (for the psycho-pedagogical and social area), Dr. Vinicio Alessandroni, manager at UMEA ASL no. 13 of Ascoli Piceno (for the area of operations). The project coordinator is Prof. Lucio Cottini.

${ }^{82}$ For more knowledge about this issue, see Articles 13 and 13bis of Regional Law no. 18, 4 June 1996, Promozione e coordinamento delle politiche di intervento in favore delle persone in situazione di handicap (Promotion and coordination of intervention policies in favour of people with disabilities), modified by Regional Law no. 28, 21 November 2000. In Article 13 (Socioeducational centres) the following is included:

1. In order to promote the development of personal autonomy and the process of social integration of people with serious disabilities who have finished their schooling, the Region supports and regulates the activation and operation of day structures.

1bis. The socio-educational daycare centres are integrated local services open to the local community for the functions of day reception, integrated socio-educational and rehabilitative support and socialization, to increase and maintain appropriate levels of functional autonomy, to counteract regression and promote employment routes through job training and supported employment. [...].

2. The socio-educational daycare centres can be equipped to ensure forms of residential facilities for people with disabilities who are without family support.

3. The region contributes towards financing in favour of single municipalities and their associates or to the Mountain Communities for the management of socio-educational centres. Article 13 bis (Residential Facilities) 1. The region contributes to finance in favour of local bodies for the establishment and operation of small residential facilities housing people with severe disabilities, lacking family support, permanently or temporarily and in cases of emergency.

${ }^{83}$ They are regulated by Regional Law no. 46 of 28 March 1995. Nuove norme per le assegnazioni e per la determinazione dei canoni degli alloggi di edilizia residenziale pubblica (New rules for assigning and levying charges for accommodation in public housing). 
centres welcoming adolescents and adults with autism relate to the structure, recommended activities and staff. The facilities must provide space for the performance of individual or cooperative activities, and must include: a room for work structured for specific types of learning (autonomy, cognitive skills, use of computer technology, communication activities, pre-employment activities, and so on), a room (or at least a private space) for the self-employed, classrooms and laboratories for work in small groups, a room used as a gym for physical activity (or possibly attendance at gyms outside the centre) and an open space.

'It's very important that the centres are located within the community context. The initiatives of the "farm community" cannot be considered satisfactory, unless as moments of a job which must always prioritise activities of interaction within a normal town environment'. ${ }^{84}$ As far as the activities are concerned, the project draws on a multi-faceted model, organizing work open to the social context and related to six main life areas linked to activities: personalized cognitive and communicative, for autonomy, social, motor and expressive, lab (pre-professional), and leisure. It is envisaged that the services activate synergies with the employment centres in order to develop projects to start working, even protected work, for those who show sufficient skill. The project is divided into four stages of implementation, for a total of 3 years. The Sotto-Progetto per l'istituzione di un servizio residenziale per soggetti con disturbi autistici (Sub-Project for the establishment of a residential service for people with autistic disorders) is part of that same project, including initiatives related to sea or mountain trips and activities to support the family, as well as the establishment of a Numero Verde Autismo (tollfree number). The Attività previste per $i$ genitori (Planned activities for parents) ${ }^{85}$ are also of great interest and are developing in two specific directions: a Progetto sollievo (Relief Project) to provide specialized assistance at particular times, and specific training courses (for parents), through which it is hoped to be able to set up local mutual-help groups, stimulated and coordinated by parents who have attended these courses.

\footnotetext{
${ }^{84}$ Regional Resolution no. 1891, 29 October 2002 L'autismo nella regione Marche-verso un progetto di vita (The Autism Project in the Marche region-towards a life project).

85 'Predicting activities of family support means not only trying to supply help in situations of great difficulty, but also laying the foundations to ensure that the family itself becomes a resource of fundamental importance in the integration process of the child. Many research projects have revealed that the family certainly needs to be helped and supported in this direction, and the level of adaptation that it is possible to achieve in many cases is generally extremely positive in the sense that they can do a lot for their children, for themselves and for the services of the community. These families are really great resources, the ideal partners for all educational and rehabilitation services, and references to other families who find themselves in similar conditions. Parents' associations in Italy have effectively compensated for the deficiencies of support services to the family, playing a supporting role in many highly significant cases. So, the equation according to which a family with an autistic child is almost inevitably destined to have a crisis and collapse is by no means a foregone conclusion. The risk, however, exists and is valid, especially if systemically organized aid procedures, in which the whole community is involved (e.g., community care) are not brought into the field'. (Ibid).
} 
The purpose of the relief project is to establish a fund to finance the presence of teachers and other specialized assistants who can take care of people with autism, adolescents and adults, for limited periods of time (a week or two), so as to allow family members to deal with personal needs (medical, work activities, periods of hospitalization, etc.), or to indulge in short holidays/days/evenings to cultivate personal interests. The parent training courses are training courses consisting of ten training units, divided into three interconnected modules. The Autism toll-free number is important for obtaining different types of information about autism, which may include the following: the location, characteristics, and activities conducted by the services, contact persons for possible specialist check-ups, the opportunity to take advantage of planned initiatives on a regional level, and so on. In addition, the Autism toll-free number is also aimed at teachers and professionals in this field so that they are able to obtain more specific information. The service is free and active for 4 days a week, alternating with the presence of technicians, social workers and parents.

In Tuscany, the 'Community Farm' project $^{86}$ sponsored by the Agrabah Association $^{87}$ in 2009, aims to achieve, in fact, a farming community in the province of Pistoia, at Gello to be precise, with the idea of providing adults with autism with the tools to develop essential skills for working in nurseries. Users are selected according to: pathology, chronological age (over 18 years), residence (Pistoia, and the province of Pistoia), and are engaged in work for 5 days a week. They are joined by a group of expert workers (specialists in horticulture) and professionals from workshops in various sectors; in fact, the work involves professional training through a variety of: workshops (sports, theatre, autonomy, communication, culinary), activities (carpentry, market, assemblies, equestrian and/or pet therapy, ceramics, découpage, music, orchestra) and field trips for the selection and purchase of materials for these activities. In the same region, the Autismo $e$ lavoro agricolo (Autism and agricultural work) project ${ }^{88}$ at the Casa di Ventignano (CdV) (Ventignano House), was set up in February 2003. The Piano di lavoro 2014 (2014 Work Plan) envisages the Project 'Autism and agriculture', aimed at five youths with autism, 4 days a week (for a total of $10 \mathrm{~h}$ ) in activities related to: work in the garden, harvesting and cleaning vegetables for crates, ${ }^{89}$ and choosing and

\footnotetext{
${ }^{86}$ The project is achieved through productive collaboration between the Association of Agrabah and the Department for the Mental Health of Adults, ASL 3 of Pistoia, which guarantees the presence of two psychiatrists who follow the planning and therapeutic evolution of the 18 users.

${ }^{87}$ It is an Association of Parents for Autism NPO.

${ }^{88}$ Approved by the Dipartimento di Salute Mentale (Department of Mental Health), the Associazione Autismo Toscana (Tuscan Autism Association) and the Cooperativa Sinergic@.

${ }^{89}$ The strategy followed by the cooperative working in the project was to produce market vegetables through buying groups, 'according to the principles of environmentally sustainable and ethically short chains, seasonality and the wholesomeness of the products, as well as respect for the rights of workers'. (Piano di lavoro 2014 del sottoprogetto 'Autismo e lavoro agricolo', 2014 Work Plan of the subproject 'Autism and agricultural work') at the Casa di Ventignano (CDV).
} 
placing them in the crates. Work activities are carried out in the greenhouse and on the land adjacent and behind it, and are recorded in the Agenda con immagini (picture diary) of each user.

In the Emilia Romagna Region, in Reggio Emilia to be precise, a bridge project called 'Job trainer disability' was established ${ }^{90}$ to support individuals with autism in practical ways in the delicate transition from school to work. The methodology involves the formation of a 'simplifier', an innovative profile that could form a 'bridge' in the transition to the world of work. 'All the reports that come to us from other countries indicate that tutor social workers do not feel prepared and equipped to meet the challenges that educational support to the disabled, especially intellectual support, requires', explained the creator of the project, Silvia Fontanesi, Cspmi European project designer. ${ }^{91}$ Hence, there was the need to develop the skills of trainers, thanks to funding from the Province of Reggio Emilia, together with the Aut Aut Association, the ASL of Reggio, the Municipality of Reggio and the provincial education system. 'Job trainer disability' [...] is a 'path to distinguish their $\mathrm{CV}$, highlighting their talents and their abilities to develop those soft skills recommended in the guidelines of the European Community and to focus and realize their projects and their dreams ${ }^{9}{ }^{92}$ In 2012, 11 teachers, 11 autistic children and as many companies and cooperatives were involved in a pilot experiment conducted in the area with encouraging results: the creation of a new professional job profile and the involvement of some of the users in working activity. In the same experiment the 'Leonardo project' was founded, which lasts 2 years (November 2013-November 2015) and which will transfer the knowledge and methodology of the job trainer to partner countries; in Reggio Emilia they are starting up the expansion of the project to people with dyslexia, Down syndrome, physical disabilities, etc.. To guarantee objectivity, this project is monitored by an external body, which is the Greek company Cyberall Access, based in Athens, which will make use of scientific collaboration from Autism-Europe. In the end, there will be about 60 newly-trained Job Trainers or Facilitators, throughout Europe.

In Friuli Venezia Giulia there is another encouraging activity, promoted by L'Officina dell'arte (The Art Workshop), a workshop for people with autism which is part of the Pordenone services network, set up by the Fondazione Bambini e Autismo ONLUS (Children and Autism Foundation NPO), which involves the active participation of all those involved in their care and welfare. The initiative for inclusion in employment is set up as a life pathway in which work, social life and residency are integrated in the context of environment and coherent organization, and includes the art workshop and the residential path, Vivi la città (Enjoy the city) projects. In the first, mosaic experts train the workers in the processing techniques

\footnotetext{
${ }^{90}$ Achieved by the Centro servizi piccole-medie imprese (Center services SMBs) (Cspmi), it has received the approval of the European Community and funding for exporting to other EU countries, such as Austria, Malta, Spain and Turkey.

${ }^{91} \mathrm{http} / / /$ www.corriere.it/salute/13_ottobre_18/così-autistici-trovano-lavoro.

${ }^{92}$ www.job.trainer.it/info.
} 
of mosaic for the manufacture of quality, useful and salable products, and the teachers themselves are, in turn, trained in the most appropriate ways to interact with people with autism, also helping them to learn social skills. The working environment is tailored for users. In fact, it is characterized by: sensory cleaning, communication support, step-by-step directions, predictability, the presence of 'coworkers', not 'assistants', the integration of the centre with other services in the network and locally. At the end of the working day the Vivi la città programme starts, which offers the opportunity to develop personal and domestic autonomy, by experiencing the city and making several choices: leaving or staying at home, going to the cinema, theatre or the pub, cooking, shopping, doing sports activities, meeting colleagues outside work, etc.

In the Region of Lazio, the recent founding of an association called 'Insettopia', deserves mention. It has the characteristics of a non-profit social organization, and has its headquarters in Rome. Its founder, journalist Gianluca Nicoletti, father of an autistic boy, has designed a format by which a group of seven to eight families of autistic people ${ }^{93}$ organize themselves like a small business, pooling public and personal resources and any possible available property and educational staff, in order to implement a large community aimed at creating an 'ideal city for autism', profitably employing technologies that allow interaction between physical and digital objects. In essence, Insettopia has the aim of becoming a mediator for concrete and effective projects between the family associations and the institutions, the tangible possibility for research, design, adapting the intended primary use of each electronic device, computer, or application, system or 'emotional prosthetic', which can facilitate the lives of people with autism spectrum disorders, offering them concrete opportunities: job placement and training, social interaction and independent living. Insettopia relies on the technology platform Snappin, developed by start-up FWR, ${ }^{94}$ which in a short time has been able to obtain the confidence of important Italian and foreign companies.

An absolute novelty in the Veneto region, is the Centro Multisistemico per l'autismo (Multisystemic Centre for Autism) project, sponsored by ViviAutismo in Padua relating to the period 2013-2014. The objectives of the Centre (CSMA) are, among other things, to promote the inclusion of people with autism spectrum disorder into the world of work since their coming of age through carrying out concrete and sustainable activities, whether held in a protected environment or not. One of the structures which is a subject of employment resource is Roncajette Park, an environmental reserve that requires a full and better use by the citizens, where users are involved in its redevelopment and where there are premises and planned specific and economically-viable activities.

\footnotetext{
${ }^{93}$ Selecting the households follows a policy of specific characteristics referring to the same age group of children with autism and to a similar level of disability.

${ }^{94}$ FWR is technological start-up aimed at developing a platform where information (digital media, services, animation) converge, engaging and involving homogeneous sets of users.
} 
The Start Autismo-Sistema territoriale per l'Autonomia e la realizzazione dei talenti di persone con autismo project (Area System-Autism Start for Autonomy and the realization of the talents of people with autism) is typical of activities from the Abruzzo Region. It is sponsored by the Foundation Il Cireneo onlus per l'autismo (The Cireneo NPO for autism) and the Focolare Maria Regina Onlus (Maria Regina Home NPO). It is funded by the European Social Fund and is networked with Italian and European partners. ${ }^{95}$ It aims to promote a positive evolutionary transition from childhood to adulthood, favouring full social inclusion and employment. Among the main activities planned for 2012-2014, there are 20 customised projects for work training, based on pilot testing at the Centro per l'Autismo in Penna di Sant'Andrea, according to an inclusive model of operation based on assessment and on the provision of services: guidance, training, job matching, coaching, mentoring and job placement, on the design and implementation of a social enterprise, the exchange of experience and dissemination of good practice in networking with European and national centres, through a digital platform. $^{96}$

In concluding this brief survey, it seems appropriate to mention two good practice projects in the international arena, namely 'Education and Professional Training (IFTS): policy and school practices for special educational needs' and the 'European Project Ispectrum'. 97 The first project was launched by the European Agency for Development in Special Needs Education, and focuses on the education and training of students with disabilities between the ages of 14 and 25 years, with the intention of promoting good practices and improvement in job opportunities and employment. The project involved more than 50 experts from 26 European countries $^{98}$ and analyzed the curricula with a view to assessing the results in relation to the labour market. From this analysis, a model for vocational education and training was developed, and some recommendations were put forward. This project, which was presented and discussed at the Cyprus Conference (November 2012), sought to identify the similarities and differences between school systems, highlighting, in particular, the factors that facilitate academic success and those that hinder it.

\footnotetext{
${ }^{95}$ The Project relies on the collaboration of the following organizations: National Autistic Society in London (United Kingdom), Specialisterne of Ballerup (Denmark), Cascina Rossago in Pavia; Faculty of Psychology, University of L'Aquila, Centro Regionale di Riferimento Autismo (Regional Centre for Autism Referral) in the Abruzzo region, Fondazione Papa Paolo VI onlus (Pope Paul VI Foundation NPO) in Pescara, Don Carlo Gnocchi Foundation, Milan, Social cooperative type B Volentieri in Casoli (Ch), Ascot Srl in Florence, Centro Terapeutico Europeo (European Therapeutic Centre) in Rignano sull'Arno (FI).

${ }^{96}$ Comunità di Pratiche sull'inserimento lavorativo dei soggetti autistici (Community of Practices in employment inclusion of people with autism).

${ }^{97} \mathrm{http} / / /$ www.ispectrum.eu/index.php/en/network.

${ }^{98}$ Austria, Belgium, Cyprus, Denmark, Estonia, Finland, France, Germany, Greece, Hungary, Iceland, Ireland, Latvia, Lithuania, Luxembourg, Malta, Netherlands, Norway, Poland, Portugal, the Czech Republic, Slovenia, Spain, Sweden, Switzerland and the United Kingdom.
} 
The second project, the 'European project Ispectrum'99 aims to improve social interaction abilities in people with autism and other special needs in the workplace by using virtual working environments that help them increase their chances of finding a job. ${ }^{100}$ In detail, in the project's 'Module 3', there is a simulated 3D work environment, based on three different virtual working environments (an IT department, a shop and a nursery), where the autistic adult can launch a Web Quest to create a concept and outline the design for his own Serious Game, have experience in using a serious 3D game, find out how this has developed and develop his own design.

\section{Conclusions}

'The removal of barriers to learning and the participation of all stakeholders at school and in social life is the cornerstone of inclusive education, whose guiding principles, rooted in the fight against discrimination, inequality and exclusion from education of the most vulnerable, in particular, are intended to guide policies and socio-cultural and economic strategies in different countries to make education for all a reality. Since 2000, 'Education for All' (EFA) is one of the central objectives among those identified as part of the Millennium Development Goals and defined during the Millennium Summit, following the adoption of the United Nations Millennium Declaration'. ${ }^{101}$ From this assumption, it can be seen that the sensitivity of the institutions and the public towards people with autism has increased over time. However, it seems necessary to continue to encourage the promotion and development of vocational training initiatives aimed at teenagers and adults, and effective support to their families, as well as opportunities for social development, through the provision of organized services, and the design of routes towards work orientation, stimulating at the same time ways to manage leisure and recreational time, based on a project of development training for the person.

In fact, 'if [...] on the one hand, autism spectrum disorders can drastically reduce the chances of a spontaneous encounter and comparison with others, on the other, they can also enhance some features that are particularly important in some areas of work: the ability to be repetitive and systematic (sometimes invaluable in activities that require a high degree of organization and precision), attention to detail (which can help locate items of information that often escape the attention of most people)'. ${ }^{102}$

It is important to remember that, at the end of the seventh annual World Autism Awareness Day, celebrated on 2 April 2014, in Italy there was a request for a law

\footnotetext{
${ }^{99}$ Bulgaria, Italy, Germany and United Kingdom.

100 'Serious Game'-Module 3.

${ }^{101}$ Chiappetta Cajola (2013).

${ }^{102}$ Pontis and Fadda (2013), pp. 9-10.
} 
determining uniform national regulations on the rights of persons with Autism Spectrum Disorders, a condition that involves the communicative, as well as the behavioral and social aspect. A few days before the approval of the Legge Regionale sull'autismo (Regional Autism Law) in Italy ${ }^{103}$ some regions filed motions for law in Parliament, calling for the adoption of the Guidelines of 2011, promulgated by the National Institute of Health, and the Guidelines approved in the State-Regions Conference in 2012. It thus seems clear that '[...] the challenge of the third millennium is to make sure that autism does not produce great disability in different areas of development. Because it is not so much autism that prevents inclusion in a normal life, but the disability produced by it to prevent it, a disability which depends on education, learning and skills' ${ }^{104}$

Open Access This chapter is distributed under the terms of the Creative Commons Attribution Noncommercial License, which permits any noncommercial use, distribution, and reproduction in any medium, provided the original author(s) and source are credited.

\section{References}

Alessandroni V (2010) Che cosa succede dopo. La gestione dell'età adulta. In: Cottini L (ed) L'autismo. La qualità degli interventi nel ciclo di vita. FrancoAngeli, Milano

Billstedt E, Gilbert IC, Gillberg C (2010) Aspetti della qualità della vita negli adulti con diagnosi di autismo in età pediatrica. Retrieved from: http://www.sagepublications.com/

Censis (2014) I disabili, più diseguali nella crescita delle diseguaglianze sociali. Press Release. Roma

Chiappetta Cajola L (2013) Per una cultura didattica dell'inclusione. In: Chiappetta Cajola L, Ciraci AM (eds) Didattica inclusiva. Quali competenze per gli insegnanti? Armando editore, Roma, pp 15-124

Chiappetta Cajola L (2014) Indagini quantitative negli studi delle disabilità e dei DSA: problemi e prospettive in ambito nazionale e internazionale. ECPS J. doi:10.7358/ecps-2014-009-chia

Corcella R (2014) Serve una legge per le persone autistiche. Corriere della sera/Neuroscienze. http://www.corriere.it/salute/neuroscienze/14_marzo_31/serve-legge-nazionale-le-personeautistiche-5e5b5dee-b8bb-11e3-917e-4c908e083af6.shtml. Accessed 31 Oct 2014

Cottini L (ed) (2010) L'autismo. La qualità degli interventi nel ciclo di vita. FrancoAngeli, Milano Giofrè F (2010) Autismo. Protezione sociale e architettura. Alinea Editrice, Firenze

Howlin P, Goode S, Hutton J, Rutter M (2004) Adult outcome for children with autism. J Child Psychol Psychiatry 45(2):212-229

Matson JL, Smith KRM (2008) Current status of intensive behavioral interventions for young children with autism and PDD-NOS. Res Autism Spectr Disord 2:60-74

McGovern CW, Sigman M (2005) Improvement in cognitive and language skills from preschool to adolescence in autism. J Autism Dev Disord 35(1):15-23

Pontis M, Fadda R (2013) Introduzione. In: Pontis M (ed) Autismo e bisogni educativi speciali. FrancoAngeli, Milano, pp 9-10

\footnotetext{
${ }^{103}$ Regional Authority for Marche (2014), Disposizioni in materia di disturbi dello spettro autistico (Provisions for Autism Spectrum Disorders).

${ }^{104}$ Corcella (2014).
} 
Raffin C (2010) Autismo Oggi. Available via Fondazione ARES. http://www.fondazioneares.com. Accessed 31 Oct 2014

Seltzer MM et al (2004) Trajectory of development in adolescents and adults with autism. Ment Retard Dev Disabil Res Rev 10(4):234-247

Uccelli di Nemi S, Barale F (2010) L'autismo nell'età adulta: profili evolutivi e modi di cura. In: Cottini L (ed) L'autismo. La qualità degli interventi nel ciclo di vita. FrancoAngeli, Milano, pp 196-197

Lucia Chiappetta Cajola is Professor of Special Education and Pedagogy at University Roma Tre, Rome, Italy. 